\title{
A Shift Towards Visualization in eLearning
}

\author{
Wei Wu, Wuxi Institute of Technology, China \\ Gulmira Bakirova, M. Auezov South Kazakhstan University, Kazakhstan \\ Ivan Trifonov, Financial University Under the Government of the Russian Federation, Russia
}

\begin{abstract}
The purpose of the study is to investigate the movement towards visualization in e-learning. The study methods include a survey and a theoretical modeling method. The study focuses on analyzing data from the 2020 public opinion survey "School Graduates and Students Expressed Their Opinion on Distance Education" by the Russian Public Opinion Research Center (VCIOM) and develops a four-tier framework model for e-learning content visualization that integrates four theories of learning, namely behaviorism, cognitivism, constructivism, and activism. The results indicate that visualization in e-learning as a trend is strongly associated with global information and communication technologies (ICTs) development. The survey by VCIOM found that $38 \%$ of surveyed students in Russia viewed their educational institutions as averagely equipped for online distance learning, $22 \%$ as well-equipped, $26 \%$ as rather well-equipped, $12 \%$ as rather poorly equipped, and $7 \%$ as poorly equipped. This study offers a content visualization framework that will make it possible to organize the teaching and learning process.
\end{abstract}

\section{KEYWORDS}

Concept, Education, eLearning, Information, Visualization

\section{INTRODUCTION}

The amount of digital content for e-learning has grown significantly over the past decade. The availability and growth of digital information create the need for tools that help students and teachers effectively organize and integrate electronic resources and seek information necessary to achieve the learning goals (Afify, 2018). One of the greatest scientific challenges of the 21 st century is how to master, organize and extract useful knowledge from the overwhelming flow of information made available by today's data collection systems and computing resources (Olcott, 2021). Visualization is the one of the means of addressing those challenges (Paletta \& Silva, 2018). Visualization tools that aid the learning process can be extremely helpful for all types of users. To understand how to improve a student's learning experience, it is important to learn how to build appropriate visual systems (Firat \& Laramee, 2018).

Information visualization performs several important educational functions at once. Visual information is more quickly perceived and assimilated in the learning process, which is associated with the peculiarities of the neurophysiological activity of the brain (Afify, 2018; Ferreira et al., 2019). Visualization allows one to transfer data in a more visual and compact form, accommodating more information in the same visual space and at the same time guaranteeing the speed and efficiency of 
its perception (Liu et al., 2020; Toetenel \& Rienties, 2016). Visualization tools can be used on mobile devices, which simplifies the provision of information and guarantees the implementation of learning principles in the 21 st century anywhere and anytime (Tijsma et al., 2020). The use of visualization tools increases the motivation and involvement of students of all ages in the learning process and thereby contributes to an increase in academic achievements and the quality of training (Dineva et al., 2019; Ginda et al., 2019; Kulasekara et al., 2011).

The efficiency and growing power of e-learning and the dissemination of software and technical means of visualization conflict with the inertia of the existing public and private education systems (Olcott, 2021; Paletta \& Silva, 2018). Research in this area has intensified after the COVID-19 pandemic as the lockdown has demonstrated the imperfection of the existing education even in developed countries (Arora \& Srinivasan, 2020). Statistical studies have also demonstrated the presence of delays, uncertainties, and doubts in the implementation of e-learning or the use of electronic data visualization in education. This problem applies equally to both school and higher education, both in developed and developing countries (Mokina \& Khoronko, 2020; Tijsma et al., 2020; Vanve et al., 2016).

It is necessary to take into account the development of e-learning for a long time, the formation of many effective teaching methods, and the emergence of more and more technical teaching aids: virtual space, cloud services, three-dimensional modeling of dynamic objects, etc. (Bognar, 2016). From the point of view of the availability of methods and technical means of teaching, the most critical factor is considered the creation of frameworks and theoretical approaches that allow harmoniously connecting the educational practice of specific countries with existing opportunities, which will allow the most effective aspects of e-learning to be implemented as quickly as possible.

\section{RELATED WORKS}

To facilitate the perception of the research background, a review of the research literature related to the research topic is divided into subsections below.

\section{Visualization In Education}

\section{Visualizing learning in a digital space}

Today, the educational process is closely related to informatization, digitalization and visualization of educational information (Mokina \& Khoronko, 2020). Data visualization allows people to easily learn and transfer knowledge they have extracted from data. Visualization techniques range from standard scatterplots and line graphs to complex interactive systems for analyzing large data volumes (Szafir, 2018).

Many concepts exist that explain what constitutes visualization. Several terms related to visualization are found in the research literature, namely visual representation, visual media, media literacy, visual communication skills, visual literacy, illustrations and media illustrations (Vavra et al., 2011). The very term "visualization" refers to the process of making an object, body, substance, product or behavior, action, process or an activity visible (Özkan et al., 2018). The general definitions and descriptions related to visualization, information, and knowledge are depicted in Table 1.

Technological innovations in e-learning are opening up numerous educational opportunities to personalize learning (adaptive learning), improve student interaction (coeducational learning) and transform the teacher's role. At the same time, e-learning is associated with the use of the Internet to provide a broad range of educational solutions that enhance knowledge and productivity (Vanve et al., 2016). The possibilities of visualization should not be underestimated in terms of educational development for people with special needs or non-native speakers by providing them with access to educational content (Valor Miró et al., 2014). In the ensuing years, more and more digital-generation 
Table 1. A summary of visualization-related concepts Source: Engelbrecht et al. (2015)

\begin{tabular}{|l|l|}
\hline Concept & Working definition \\
\hline Visualization & $\begin{array}{l}\text { A field of study concerned with the transformation of data to visual representations, where the } \\
\text { goal is the effective and efficient cognitive processing of data }\end{array}$ \\
\hline Information & $\begin{array}{l}\text { The result of extracting meanings from lower level data, either through a computational } \\
\text { process or by means of human transcription }\end{array}$ \\
\hline Knowledge & $\begin{array}{l}\text { The result of a cognitive process, either through computer simulation or by means of human } \\
\text { knowledge transcription, resulting in a higher level of human understanding }\end{array}$ \\
\hline $\begin{array}{l}\text { Information } \\
\text { Visualization }\end{array}$ & $\begin{array}{l}\text { The transformation from lower-level data to visual representations of meanings extracted from } \\
\text { the data, where the extraction is either a computational process or a human transcription } \\
\text { process; the aim is to explore data and create new insights }\end{array}$ \\
\hline $\begin{array}{l}\text { Knowledge } \\
\text { Visualization }\end{array}$ & $\begin{array}{l}\text { The transformation from knowledge to visual representations of the knowledge, where the } \\
\text { knowledge is the result of a cognitive process resulting from either computer simulation or } \\
\text { human transcription; the aim is to improve the transfer of knowledge between humans }\end{array}$ \\
\hline
\end{tabular}

people will participate in the transformation of educational institutions, starting changes that best suit their needs, learning styles, and interests (Dineva et al., 2019).

\section{Visualization As A Means of Taking Up e-Learning Challenges}

The quality of e-learning courses currently needs improvement. One of the means is visualization and interactive support. Examples include interactive video lectures, interactive exercises, instant messaging, forums, webinars, quizzes, and more (Kolesnikov et al., 2019).

One of the challenges for educators who use an e-learning environment is to understand the learners' needs. One way to deal with this issue is to collect data about learners' actions and interactions with the e-learning environment and analyze it to tailor the content to learners' needs and profile (Moissa et al., 2014). Using a classic table of content inherited from the written literature will limit the ability to build adaptive e-learning content effectively (Bargel et al., 2012).

\section{Advantages of Visualization In E-Learning}

The e-learning provides multiple learning opportunities that stem from a wealth of accessible online information (Kuosa et al., 2016). The general consensus on e-learning is that visualization is an effective learning tool (Szafir, 2018). Visual effects make it much easier to understand the information being conveyed (Rajasekaran \& Arulchelvan, 2017). Visualization allows learners and educators to become aware of several features previously not easily discoverable from the raw interaction data (Yu et al., 2011). Providing visual explanations is more beneficial than using verbal methods, in part, because visual explanations map information more directly than verbal ones (Bobek \& Tversky, 2016).

\section{Types and Forms of Visual Communication In Education}

\section{Features of Visual Demonstration}

Visual demonstrations come in a variety of formats, complexity, levels of abstraction, and levels of interaction. The least interactive (other than a static image) is a simple animation, such as flash, which only allows the user to control the playback buttons. More sophisticated visualizations allow the user to manipulate elements of the environment, such as the input data, environmental parameters, or constraints to see the effects of these changes. Where and how the visualizations are used also varies. They can be used for classroom demonstrations, as laboratory exercises, embedded in online learning materials, as homework or pre-class exercises, or made available as reference material (Schweitzer \& Brown, 2007). 
The Information may be presented in a graphic way and the graphic visual representations of information or infographics used in the classroom come in multiple forms, each serving a different purpose. Infographics may be employed when creating presentations, mnemonic diagrams, and various models of objects and processes (Tarkhova et al., 2020).

\section{Visualization Tools In e-Learning}

E-learning is the interaction of teaching/learning process and technologies, encompassing a broad range of activities, from computer-based learning to education conducted entirely in online environment (Magdalena, 2011). The rapid growth of computer-aided visualization methods and virtual reality technologies has led to the possibility of visualizing information better and creating a virtual space for teaching net-generation learners (Liu et al., 2020).

The synergy between the fields of computer graphics, human-computer interaction, and data mining enhances research in information visualization so that the user can use visual perceptions to better analyze and understand the information. It is a topic characterized by the need to create mechanisms to transform data into information, and whose presentation should express important properties of the data and how different items relate to each other (Ferreira et al., 2019).

To improve learners' perception of information, novel analytic visualization tools can be developed that capture the key structural and dynamical aspects of the personalized learning path at ever higher levels of detail and in a way that is truly effective for learners, educators, and corporate partners. Ultimately, companies and other institutions are interested in providing high-quality, effective online education that keeps up with the accelerating pace of science and technology (Ginda et al., 2019). An interactive learning environment is an idea that many educators welcome in their search for new methods and support for learners (Mierlus-Mazilu, 2008).

The structure of this paper is as follows. Introduction highlights the relevance of this study. Related works section presents a thematic selection of papers dedicated to e-learning and visualization. The current section is divided into subsections to better present the essence of visualization as a tool for improving e-learning and teaching the basic concepts and technologies. The next section presents the research materials and methods, followed by the main part of the study, discussion, and then conclusions.

This study focuses on investigating the tendency towards visualization in e-learning. The study looks at the very idea of visualization, analyzes the main types and forms of visuals used in education, and builds a framework for effective visualization of online learning.

The motivation for this study was the lack of academic research on country analysis of the use of visualization tools in e-learning and the study of the current state and real needs of the education systems of individual countries in the situation before and during the COVID-19. In this situation, the need for developed e-learning within education systems has sharply intensified. The research question is: how are ICTs used for teaching, and what is the real state of e-learning in Russia in connection with the use of visualization tools? The answer to this question is the framework developed by the authors for the use of visualization in e-learning. The practical significance of the research is presented in the form of identifying the weaknesses and needs of the education system in the field of e-learning and using the proposed framework as a basis for creating e-learning curricula.

\section{MATERIALS AND METHODS}

\section{Research Design}

For research purposes, the results of a public opinion survey conducted by the Russian Public Opinion Research Center (VCIOM) on May 14-16, 2020 were used. The survey method is a telephone interview on a stratified two-base random sample of landline and mobile numbers found in the complete list of telephone numbers used in the Russian Federation. A sample consistent with the study objectives 
was defined. The all-Russian survey and socio-demographic criteria are described below. The study uses descriptive statistics to assess the needs for e-learning and how to visualize it. For a comparative assessment of the situation in the field of education, the open data of UNESCO Institute for Statistics for 2018 are used (the latest publicly available on education). Data before the COVID-19 pandemic are used, which is associated with incomplete verification of statistical data obtained by international organizations during the pandemic.

\section{Sample Study}

The survey sample consists of 1092 parents with at least one child who have graduated from an educational institution (school, gymnasium, or lyceum), 400 college students, and 800 university students. With $95 \%$ probability, the maximum margin of error ranges between 3 and $4.9 \%$. This ensures the statistical relevance and representativeness of the sample.

The survey was conducted anonymously and all respondents were informed that data would only be used for the scientific purposes.

The content visualization framework was developed through conducting a systematic analysis and synthesizing the key theories of learning, namely behaviorism, cognitivism, constructivism, and activism. The proposed methodological approach is based on the idea that e-learning can be carried out using any theory of learning by applying electronic devices (Bognar, 2016) and aims to build knowledge and skills in order to enhance the quality of learning (A. Pange \& J. Pange, 2011).

\section{Data Analysis}

All submitted data were recalculated in accordance with the rule of maintaining the homogeneity of the socio-demographic criteria of the main survey, while maintaining the ratio and weighting factors of all demographic and social groups of the respondents. Thus, the present sectoral study retains the statistical reliability of the sample and the validity characteristic of the baseline study in relation to the entire population of the Russian Federation, as to the general sample.

\section{Instruments}

For the secondary analysis of descriptive statistics obtained during the survey, as well as for visualization of the presented data, the Microsoft Excel 2019 software package was used.

\section{Research Limitations}

The study is limited to a survey that covers e-learning trends of 2020 and examines possibilities of using visualization as a tool in the educational process. The study is limited to descriptive sectoral statistics and covers only an individual country, while the conditions for the development of technologies and teaching methods can differ significantly from country to country. There was no analysis for specific demographic categories or territories, which may expand the relevance of the study in future studies. It is also necessary in the future to use updated statistics obtained after the COVID-19 pandemic.

\section{RESULTS}

Based on the education attainment levels of the population measured by the United Nations every two years, Russia ranks 33rd among 189 countries in the world with an Education Index of 0.832, while Kazakhstan ranks 38th with the Education Index of 0.817, indicating the above-average performance of the education sector. For comparison, many countries in Europe are inferior to Russia and Kazakhstan in education attainment. For example, Italy ranks 49th, even though it spends more on education when compared to these countries (Figure 1).

Source: UNESCO Institute for Statistics (n.d.) 
Figure 1. Government expenditure on education, total (\% of GDP) as of 2018 (data given for selected countries)

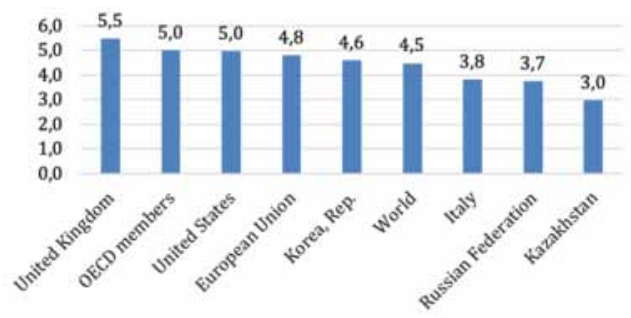

Table 2. How well is your educational institution equipped for online distance learning?

\begin{tabular}{|l|l|}
\hline Answer & Frequency \\
\hline Well-equipped & $22 \%$ \\
\hline Rather well-equipped & $16 \%$ \\
\hline Averagely equipped & $38 \%$ \\
\hline Rather poor-equipped & $12 \%$ \\
\hline Poor-equipped & $7 \%$ \\
\hline Not sure & $5 \%$ \\
\hline
\end{tabular}

Note: percentages are of total survey respondents (university students). The survey question type was closed-ended single-choice question.

Source: Initiative all-Russian poll by VCIOM-Sputnik (2020)

At the same time, Russia faces a significant lag in many areas of e-learning development, ranging from technology infrastructure to visual practices. In the student survey conducted in Russia in $2020,38 \%$ of respondents reported that their educational institutions were equipped for online distance learning averagely, 22\% said they were well-equipped, and 7\% described their educational institutions as poorly equipped (Table 2). Furthermore, $16 \%$ of responses were rather well-equipped and $12 \%$ - rather poor-equipped.

While infrastructure issues can be resolved with appropriate state policy and funding, the quality of the teaching staff requires no significant attention. The survey results indicate that the majority of respondents felt rather positive about the quality of online learning practices, which have been introduced over the past years in many educational institutions throughout Russia (Table 3).

Table 3. How would you describe the quality of online learning in your educational institution?

\begin{tabular}{|l|l|}
\hline Answer & Frequency \\
\hline High & $25 \%$ \\
\hline Rather high & $28 \%$ \\
\hline Moderate & $32 \%$ \\
\hline Rather low & $8 \%$ \\
\hline Low & $4 \%$ \\
\hline Not sure & $3 \%$ \\
\hline
\end{tabular}

Note: percentages are of total survey respondents (university students). The survey question type was closed-ended single-choice question.

Source: Initiative all-Russian poll by VCIOM-Sputnik (2020) 
Table 4. The use of ICTs in teaching and learning process in 2018. Source: OECD (2018)

\begin{tabular}{|c|c|c|c|c|c|c|c|c|c|c|}
\hline \multirow[b]{2}{*}{ Variable } & \multicolumn{10}{|c|}{ ICT for teaching } \\
\hline & \multicolumn{2}{|c|}{$\begin{array}{l}\text { Teachers } \\
\text { reporting a high } \\
\text { level of need } \\
\text { for professional } \\
\text { development in } \\
\text { ICT skills for } \\
\text { teaching }\end{array}$} & \multicolumn{2}{|c|}{$\begin{array}{l}\text { Principals } \\
\text { reporting } \\
\text { shortage or } \\
\text { inadequacy } \\
\text { of digital } \\
\text { technology for } \\
\text { instruction }\end{array}$} & \multicolumn{2}{|c|}{$\begin{array}{l}\text { Teachers who } \\
\text { 'frequently' } \\
\text { or 'always' let } \\
\text { students use } \\
\text { ICT for projects } \\
\text { or class work }\end{array}$} & \multicolumn{2}{|c|}{$\begin{array}{l}\text { Teachers for } \\
\text { whom the 'use } \\
\text { of ICT for } \\
\text { teaching' was } \\
\text { included in } \\
\text { their formal } \\
\text { education or } \\
\text { training }\end{array}$} & \multicolumn{2}{|c|}{$\begin{array}{l}\text { Teachers } \\
\text { who felt 'well } \\
\text { prepared' or } \\
\text { 'very well } \\
\text { prepared' for } \\
\text { the use of ICT } \\
\text { for teaching }\end{array}$} \\
\hline Unit & \multicolumn{10}{|c|}{ Percentage } \\
\hline Measure & Value & S.E. & Value & S.E. & Value & S.E. & Value & S.E. & Value & S.E. \\
\hline England (UK) & 5.3 & 0.6 & 14.5 & 2.7 & 41.3 & 1.4 & 74.7 & 1.1 & 50.7 & 1.1 \\
\hline Italy & 16.6 & 0.7 & 30.9 & 3.8 & 46.6 & 1.2 & 52.2 & 0.9 & 35.6 & 1.0 \\
\hline Kazakhstan & 30.2 & 0.9 & 44.8 & 3.9 & 65.7 & 1.2 & 75.1 & 1.0 & 68.8 & 1.0 \\
\hline Russian Federation & 14.6 & 0.9 & 31.7 & 4.7 & 69.0 & 1.1 & 68.7 & 1.1 & 71.5 & 1.3 \\
\hline United States & 10.2 & 1.8 & 19.3 & 9.2 & 60.1 & 2.9 & 62.7 & 1.3 & 44.8 & 2.9 \\
\hline OECD average & 17.7 & 0.2 & 24.6 & 0.7 & 52.7 & 0.3 & 56.0 & 0.2 & 42.8 & 0.2 \\
\hline
\end{tabular}

For instance, $25 \%$ of respondents described the quality of online learning as high, $28 \%$ selected rather high to express their opinion on the matter, and 35\% viewed it as moderate. A very small portion of students said that e-learning practices were less than moderate in quality. It is important to understand that the high quality of teachers is one of the forces counteracting the slow pace of e-learning integration in Russia.

The effective use of visualization tools when teaching online will help to partially overcome the e-learning backlog that happened as a result of technology infrastructure issues and the lack of funding. In general, looking at the OECD statistics regarding the level of use of information and communication technologies by teachers, significant differences can be seen between single countries (Table 4).

Table 4 shows that in Kazakhstan, a substantial portion (30.2\%) of teachers felt the need for ICT professional development, while in Russia - 14.6\%. At the same time, Kazakhstan had the highest level of ICT integration in professional training (75.1\%) and Russia had a lower ICT integration level $(68.7 \%)$ but not the lowest among the examined countries. The teachers' perception of their own digital competence is another issue that is important and should be addressed. The percentage of teachers who felt well prepared or very well prepared for the use of ICT in the teaching context varied significantly from country to country: $71.5 \%$ in Russia, $68.8 \%$ in Kazakhstan, and $35.6 \%$ in Italy.

Visualization, to some extent, can be considered as a means for qualitatively improving the teaching and learning process through the use of ICTs and the synthesis of practices from other fields, such as psychology, statistics, marketing, etc. At the same time, the capacity of technology (ICT) based infrastructure for visualization of learning can be extended through the synthesis of different theories of learning, namely behaviorism, cognitivism, constructivism and activism. The proposed framework for this is depicted in Figure 2.

Source: developed by the authors through synthesizing four theories of learning offered by Bognar (2016)

The theory of constructivism embedded in the framework above holds that the use of visual aids by educators will enable learners to promote independent thinking skills and learn how to find necessary information in a narrow space of time. The theory of behaviorism suggests that learners react in different ways to visuals. The component of cognitivism implies learners developing practical 
Figure 2. The model showing components of effective e-learning content visualization

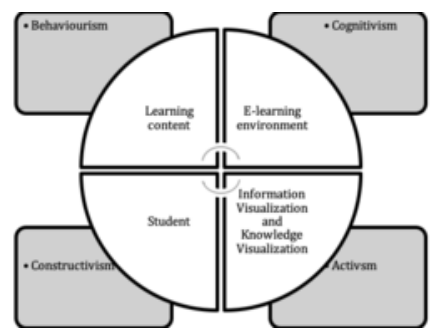

skills to be able to realize effective and efficient use of knowledge. It should be noted that the most important contribution of this work is that the proposed framework can be integrated into the teaching and learning practice to enhance the e-learning process with visual solutions.

\section{DISCUSSION}

An approach where single components of visualization are examined has been previously used in many similar studies. This is especially the case of studies concerned with the effectiveness of visual aids in education. Scholars emphasize that learners perform better, have stronger learning motivation, and are more active in the classroom when instructors apply innovative methods of visualization (Dineva et al., 2019). Using visual aids enables educators to address learners' memory weaknesses and convey additional information. Learners exposed to more than one type of visualization are likely to learn more and divide their attention between items (Liu et al., 2020). A well-made visual aid can help learners better understand what the educator delivers but the input data converted into the aid should be familiar to learners and pique their interest (Silius et al., 2013). The results show that by visualizing the design in advance, educators focused less on traditional teaching models such as the learn-practice-apply model. Notably, by visualizing initial decisions, educators create more student-centered and creative projects aimed at developing a range of skills that support students both academically and in the workplace (Toetenel \& Rienties, 2016).

Video-based learning is becoming more prominent in the world of education, Giannakos et al. (2014) say. Videos in education allow overcoming the practical constrains of the real world and explore the far greater opportunities offered by digital spaces (Giannakos et al., 2014). Multimedia technology broadly refers to the development and the use of various types of media and communication technologies to improve content visualization and user experience. The integration of multimedia technologies into the classroom is becoming a core part in the development of e-learning technologies (Lau et al., 2014). Technological progress opens up new possibilities to visualize learning content. A visual aid will be effective if it meets the following criteria: clarity, the use of contrasting and associative colors, an eye-catching design, ease to read, simple graphics (diagrams, tables, etc.), consistency between items, and high quality of photographs and printed materials (Mokina \& Khoronko, 2020). An instructional design based on Gagnier's nine instructions and Mayer's cognitive theory of multimedia learning, with extensive use of animation with storytelling, is demonstrated to be effective in explaining abstract processes. Such innovations have enabled active learning, visualizing dynamic abstract processes, and testing learners with immediate feedback, enabling them to achieve meaningful learning experiences (Kulasekara et al., 2011).

Today, using just one visualization tool is not enough. It is necessary to enhance the learning process through the synthesis of different models of learning, namely behaviorist, cognitivist, constructivist, and activist ones. Although each theory and model of learning could find its place in the realization of e-learning, it should not be reduced to the use of programmed instructions and 
multimedia contents. It is important that learners can shape their own understanding through interaction with their peers and teachers (Bognar, 2016).

\section{CONCLUSION}

Visualization is the process of representing information visually for educational or research purposes. The results of the study indicate that visualization in e-learning is a trend strongly associated with the global ICT development. At the same time, the extent and possibilities of using visualization in education largely depend on the state of technology infrastructure and the quality of the teaching staff. The public opinion survey by VCIOM found that $38 \%$ of surveyed students in Russia viewed their educational institutions as averagely equipped for online distance learning and other 38\% thought that they had better-than-average level of technological preparation. At the same time, $7 \%$ described their educational institutions as poorly equipped. In addition, this study offers a content visualization framework that will make it possible to organize the teaching and learning process in a digital space effectively. The proposed framework integrates four theories of learning, namely behaviorism, cognitivism, constructivism and activism. The results of the study may be useful in enhancing visual distance learning. 


\section{REFERENCES}

Afify, M. (2018). E-learning content design standards based on interactive digital concepts maps in the light of meaningful and constructivist learning theory. Journal of Technology and Science Education, 8(1), 5-16. doi: $10.3926 /$ jotse. 267

Arora, A. K., \& Srinivasan, R. (2020). Impact of pandemic COVID-19 on the teaching-learning process: A study of higher education teachers. Prabandhan: Indian Journal of Management, 13(4), 43-56. doi:10.17010/ pijom/2020/v13i4/151825

Bargel, B., Schröck, J., Szentes, D., \& Roller, R. (2012). Using learning maps for visualization of adaptive learning path components. International Journal of Computer Information Systems and Industrial Management Applications, 4, 228-235.

Bobek, E., \& Tversky, B. (2016). Creating visual explanations improves learning. Cognitive Research: Principles and Implications, 1(1), 27. doi:10.1186/s41235-016-0031-6 PMID:28180178

Bognar, B. (2016). Theoretical backgrounds of e-learning. Croatian Journal of Education, 18(1), 225-256. doi:10.15516/cje.v18i1.1475

Dineva, S., Nedeva, V., \& Ducheva, Z. (2019). Digital generation and visualization in e-learning. In The 14th International Conference on Virtual Learning, ICVL 2019 (pp. 183-189). Academic Press.

Engelbrecht, L., Botha, A., \& Alberts, R. (2015). Designing the visualization of information. International Journal of Image and Graphics, 15(2), 1-20. doi:10.1142/S0219467815400057

Ferreira, H., de Oliveira, G. P., Araújo, R., Dorça, F., \& Cattelan, R. (2019). Technology-enhanced assessment visualization for smart learning environments. Smart Learning Environments, 6(1), 14. doi:10.1186/s40561019-0096-z

Firat, E., \& Laramee, R. (2018). Towards a survey of interactive visualization for education. In G. Tam \& F. Vidal (Eds.), Conference: Computer Graphics Visual Computing (CGVC) (pp. 1-11). The Eurographics Association.

Giannakos, M., Chorianopoulos, K., Ronchetti, M., Szegedi, P., \& Teasley, S. (2014). Video-based learning and open online courses. International Journal of Emerging Technologies in Learning, 9(1), 4-7. doi:10.3991/ ijet.v9i1.3354

Ginda, M., Richey, M. C., Cousino, M., \& Börner, K. (2019). Visualizing learner engagement, performance, and trajectories to evaluate and optimize online course design. PLoS One, 14(5), e0215964. doi:10.1371/journal. pone.0215964 PMID:31059546

Initiative all-Russian poll by VCIOM-Sputnik. (2020). School graduates and students expressed their opinion on distance education. Retrieved December 20, 2020, from https://wciom.ru/index.php?id=236\&uid=9919

Kolesnikov, A. M., Lomachenko, T. I., Kokodey, T. A., Khitushchenko, V. V., \& Mihailov, Y. I. (2019). A strategy of visualization and interactive support for university level educational digitalization. In 2019 IEEE Conference of Russian Young Researchers in Electrical and Electronic Engineering (EIConRus) (pp. 1412-1414). IEEE. doi:10.1109/EIConRus.2019.8657211

Kulasekara, G. U., Jayatilleke, B. G., \& Coomaraswamy, U. (2011). Learner perceptions on instructional design of multimedia in learning abstract concepts in science at a distance. Open Learning, 26(2), 113-126. doi:10.1 080/02680513.2011.567459

Kuosa, K., Distante, D., Tervakari, A., Cerulo, L., Fernández, A., Koro, J., \& Kailanto, M. (2016). Interactive visualization tools to improve learning and teaching in online learning environments. International Journal of Distance Education Technologies, 14(1), 1-21. doi:10.4018/IJDET.2016010101

Lau, R. W. H., Yen, N. Y., Li, F., \& Wah, B. (2014). Recent development in multimedia e-learning technologies. World Wide Web (Bussum), 17(2), 189-198. doi:10.1007/s11280-013-0206-8

Liu, Z.-J., Levina, V., \& Frolova, J. (2020). Information visualization in the educational process: Current trends. International Journal of Emerging Technologies in Learning, 15(13), 49-61. doi:10.3991/ijet.v15i13.14671 
Magdalena, I. N. (2011). The use of distributed databases in e-learning systems. Procedia: Social and Behavioral Sciences, 15, 2673-2677. doi:10.1016/j.sbspro.2011.04.168

Mierlus-Mazilu, I. (2008). Distance education; e-learning solution. International Journal of the Computer, the Internet and Management, 16, 1-6.

Moissa, B., de Carvalho, L. S., \& Gasparini, I. (2014). A web analytics and visualization tool to understand students' behavior in an adaptive e-learning system. In P. Zaphiris \& A. Ioannou (Eds.), Lecture Notes in Computer Science: Vol. 8523. Learning and Collaboration Technologies. Designing and Developing Novel Learning Experiences. LCT 2014 (pp. 312-321). Springer. doi:10.1007/978-3-319-07482-5_30

Mokina, A., \& Khoronko, L. (2020). The role of design and visualization of handouts in the process of training personnel for the agro-industrial complex. E3S Web of Conferences, 175, 15008. .10.1051/e3sconf/202017515008

OECD. (2018). Teaching and Learning International Survey (TALIS). Retrieved December 20, 2020, from https://www.oecd.org/education/talis/

Olcott, D. (2021). Open and distance education theory revisited: Implications for the digital era. Open Learning, 36(1), 105-108. Advance online publication. doi:10.1080/02680513.2020.1859998

Özkan, A., Arikan, E., \& Özkan, E. (2018). A study on the visualization skills of 6th grade students. Universal Journal of Educational Research, 6(2), 354-359. doi:10.13189/ujer.2018.060219

Paletta, F., \& Silva, A. (2018). Information access in the digital era: Document visualization strategy. In F. Ribeiro $\&$ M. Elisa Cerveira (Eds.), Challenges and Opportunities for Knowledge Organization in the Digital Age, Series: Advances in Knowledge Organization (Vol. 16, pp. 597-605). Ergon. doi:10.5771/9783956504211-597

Pange, A., \& Pange, J. (2011). Is e-learning based on learning theories? A literature review. International Journal of Social, Behavioral, Educational, Economic, Business and Industrial Engineering, 5(8), 932-936. doi:10.5281/zenodo.1079602

Rajasekaran, S. K., \& Arulchelvan, S. (2017). An experimental study on impact of visuals in e-Learning content of art and media. International Journal of Emerging Trends in Science and Technology, 4(8), 5816-5819.

Schweitzer, D., \& Brown, W. (2007). Interactive visualization for the active learning classroom. In Proceedings of the 38th SIGCSE Technical Symposium on Computer Science Education - SIGCSE '07 (pp. 208-212). SIGCSE. doi:10.1145/1227310.1227384

Silius, K., Tervakari, A.-M., \& Kailanto, M. (2013). Visualizations of user data in a social media enhanced web-based environment in higher education. 2013 IEEE Global Engineering Education Conference (EDUCON), 8(2), 13-19. doi:10.1109/EduCon.2013.6530212

Szafir, D. (2018). The good, the bad, and the biased: Five ways visualizations can mislead (and how to fix them). ACM Journals, 25(4), 26-33. doi:10.1145/3231772

Tarkhova, L., Tarkhov, S., Nafikov, M., Akhmetyanov, I., Gusev, D., \& Akhmarov, R. (2020). Infographics and their application in the educational process. International Journal of Emerging Technologies in Learning, 15(13), 63-80. doi:10.3991/ijet.v15i13.14647

Tijsma, G., Hilverda, F., Scheffelaar, A., Alders, S., Schoonmade, L., Blignaut, N., \& Zweekhorst, M. (2020). Becoming productive 21 st century citizens: A systematic review uncovering design principles for integrating community service learning into higher education courses. Educational Research, 62(4), 390-413. doi:10.108 0/00131881.2020.1836987

Toetenel, L., \& Rienties, B. (2016). Learning Design - creative design to visualise learning activities. Open Learning, 31(3), 233-244. doi:10.1080/02680513.2016.1213626

UNESCO Institute for Statistics. (n.d.). Retrieved December 20, 2020, from http://uis.unesco.org/

Valor Miró, J. D., Spencer, R. N., Pérez González de Martos, A., Garcés Díaz-Munío, G., Turró, C., Civera, J., \& Juan, A. (2014). Evaluating intelligent interfaces for post-editing automatic transcriptions of online video lectures. Open Learning, 29(1), 72-85. doi:10.1080/02680513.2014.909722

Vanve, A., Gaikwad, R., \& Shelar, K. (2016). A new trend e-learning in educations system. International Research Journal of Engineering and Technology, 3(4), 299-302. 
Vavra, K., Janjic-Watrich, V., Loerke, K., Phillips, L., Norris, S., \& Macnab, J. (2011). Visualization in science education. Alberta Science Education Journal, 41(1), 22-30.

Yu, B., Ullrich, C., \& Shen, R. (2011). Visualization of students' activities to support teachers and students in personal learning environments. In Proceedings of The Iadis International Conference on Internet Technologies \& Society (ITS 2011) (pp. 1-8). ITS. 